\title{
GOVOR PREDSEDNIKA DRŽAVNEGA SVETA REPUBLIKE SLOVENIJE ALOJZA KOVŠCE OB DNEVU REFORMACIJE 2020
}

Spoštovane državljanke in državljani Republike Slovenije, v duhu manire očeta slovenskega naroda Primoža Trubarja "Lubi Slovenci«,

nocoj praznujemo dan reformacije, državni praznik kot spomin na poseben zgodovinski mejnik - na reformacijsko gibanje v 16. stoletju, ki je za obstoj slovenskega naroda in nastanek samostojne slovenske države neprecenljivo.

Pred dobrimi petsto leti, natančneje 31. oktobra 1517, je zaradi nevzdržnih razmer v Cerkvi nemški duhovnik Martin Luther cerkvenim oblastnikom poslal protestno pismo, ki mu je priložil znamenitih 95 tez in s tem zanetil reformacijsko gibanje po vsej Evropi in svetu. Prelomno dejanje se je rodilo iz čistega upora, upora do nevzdržnih razmer in pritiskov, upora do krivic in krivičnosti cerkvenih oblastnikov ... Duh reformacije je za vselej osvojil Evropo in z njo slovenske dežele. Reformacija je svetu prinesla osvoboditev od spon preteklosti, pomenila je avantgardo s poudarkom na drznosti upati si gledati naprej. Vemo, kako viharno se je nato obračal tok zgodovine in kako uspešno smo Slovenke in Slovenci krmarili v teh vodah. Proces celostnega preoblikovanja, kar reformacija v svojem bistvu tudi je, je trajal vse do nastanka lastne države Republike Slovenije.

Petsto let kasneje se je pater Karel Gržan na svojstven način priklonil duhovnim voditeljem takratnega protestantskega gibanja na Slovenskem. Z aktualizacijo 95-ih tez je začutil klic, da se mora duh reformacije preleviti v novo obliko upora, temelječega na opolnomočenem 
posamezniku, in ob tem zapisal: »Kakor so $v$ preteklosti temeljile reformacije na posameznikih, tako temelji prebujanje v naših dneh na ozaveščenih samostojnih avtonomnih posameznih osebnostih." Veliki slovenski reformatorji, Primož Trubar, Jurij Dalmatin, Adam Bohorič in drugi, so postavili temelje slovenstva, podlago za narodnostno prebujanje, pogum, samozavest in končno tudi zrelost, da se lahko danes kot narod uspešno kosamo $\mathrm{z}$ mnogo številčnejšimi narodi, ki jih spremljata večtisočletni zgodovina in tradicija. A nič od tega ne sme za nas biti samoumevno.

Današnji praznik je tako enkratna priložnost, da se poklonimo našim velikanom reformacije in protestantizma. Velikanom, ki so imeli neomajno voljo in odločnost, predvsem pa pripadnost nečemu, kar je tlelo tiho in vztrajno v ozadju strogih družbenih pravil, nedotakljivosti cerkvenih oblasti ter nepredstavljivih socialnih razlik v takratni družbi z obrobja. Imeti rad poštenega in delavnega človeka, preprostega in bogaboječega Slovenca, to je bilo osrednje gonilo Primožu Trubarju, da je $\mathrm{v}$ svojih knjigah $\mathrm{v}$ jasnem in rojakom razumljivem jeziku $\mathrm{z}$ različnih vidikov in na različne načine oznanjal krščanski nauk. Mi smo ponosni dediči te reformacijske zakladnice, ki nam je prinesla slovenski knjižni jezik, med prvimi v Evropi smo dobili prevod Svetega pisma ter več kot 50 slovenskih knjig.

Na nas je, da znamo prepoznati temeljno spoštovanje do izročila reformacije, ki je zaradi svoje daljnosežne politične in kulturne vloge preseglo prvotni verski pomen. Izročila, ki nam lahko $\mathrm{v}$ teh res hudih in težkih koronačasih pomagajo preživeti, pa ne le preživeti, temveč dobro in polno živeti.

Skozi zgodovino smo Slovenci trmasto dokazali, da ni pomembno, kako velik je narod, da obstane, pomembno je, kako veliko ima narodno zavest. Spoštujmo svoj jezik, svojo kulturo in zgodovinsko izročilo $\mathrm{z}$ namenom, da trmasto in ponosno uveljavimo svojo edinstvenost kot narod, država in kot posamezniki.

Pa vendar bi se na tem mestu dotaknil razmišljanja o tem, da je identiteta brez jezika pravzaprav kot telo brez duše in da moramo kot država in kot državljani Slovenije za svoj materni jezik skrbeti bolje, kot smo to 
počeli doslej. Srčnejše in odgovornejše. Odločneje in ponosneje. Izzivi globalizacije so namreč slovenskemu jeziku nastavili prebrisano past: toplo so ga povabili v družbo velikih, kjer pa je z veljavo začel izgubljati kompetitivne prednosti. Primož Trubar je spodbujal ljubezen do branja v maternem jeziku v času velikih preizkušenj, v času ponemčevanja in splošnega zaničevanja slovenskega kmečkega življa. Kako znamo spodbujati branje v maternem jeziku pol tisočletja kasneje? Ko spremljam svoje otroke, to mlado generacijo, ki tekoče govori mnogo tujih jezikov, ki se željna znanj in priložnosti spogleduje bolj s tujino kot $z$ domovino, me skrbi naša prihodnost. Kako bo preživel narod s pomanjkljivim poznavanjem lastnega jezika in kulture, kako bo preživel narod brez svojih nadarjenih in inovativnih mladih upov?

Ne rodimo se namreč $z$ občutkom za domovino in narodno pripadnost. Identitetni stik z domovino moramo negovati, privzgojiti, pridobiti in si ga celo zaslužiti. To je naše skupno poslanstvo, ki ga moramo predati bodočim rodovom kot enotni, četudi smo večkrat razdvojeni in v mnogem raznoliki. Domoljubje pomeni čutiti dolžnost do prednikov in hkrati do potomcev. Stati inu obstati niso prazne marnje, gre za polno moč zavedanja samega sebe, sobivanja $z$ drugimi ter spodbujanja medgeneracijske solidarnosti in odgovornosti. Povedano drugače, odgovoriti si moramo na tri ključna vprašanja: kje živimo, kako živimo in s kom živimo ...

Reformacija in protestantizem sta nam podarila priročno orodje luč v obliki zdravega razuma, ki je zagorela $\mathrm{z}$ razsvetljenstvom in nam trajno podarila svobodno voljo ter odgovornost za svoje okolje, deželo, jezik, postavo in državo. $\mathrm{V}$ ogroženosti in prizadetosti se politika še bolj polarizira na naše in vaše, namesto enotnosti in miru je vse več medsebojnih konfliktov, namesto besed sočutja se obmetavamo s sovražnim govorom. Kulturna, socialna, rasna ali verska drugačnost ne sme biti razlog za napetosti v družbi. Ni naključje, da so pobudo za ta praznik podali ljudje, živeči ob Muri, kjer so že v preteklosti znali in zmogli spodbujati sožitje med drugače verujočimi pa tudi mislečimi. Pluralizem da, a ne zgolj kot mrtva črka na papirju, temveč kot odsev realnega vsakdanjega življenja. Pozitiven zgled medsebojnega spoštovanja se je tako usidral 
v praktično življenje ravno $v$ časih, ko iz ljudi privre najslabše. In to je ljudi obvarovalo med vojno in to lahko ljudi obvaruje v času epidemije nove koronavirusne bolezni COVID-19. Medverski dialog, politična korektnost, medgeneracijska solidarnost ter socialna občutljivost - ta roža strpnosti zacveti šele $\mathrm{v}$ viharju, mi je na zadnjem srečanju zaupal novi škof Evangeličanske cerkve gospod Leon Novak, in še kako prav ima.

Protestantska etika nam ponuja konkretne usmeritve za življenje, njene vrednote, kot so ljubezen, pravičnost, usmiljenje, spoštovanje, pa so tako globoko zakoreninjene $\mathrm{v}$ človeški dobroti in bistvu, da jih ne bo težko z malo truda obuditi. Svet se znova spreminja. Reforma sveta, družbe, znanj in misli je dolgoročen proces, ki se odvija tukaj in zdaj. Izkoristimo krizo za tak preporod. Glejmo na svet s pozitivne strani, opazimo drug drugega, ne bodimo ozkogledni, pohlepni in sebični. Opazimo tiste, ki se izpostavljajo za nas - medicinsko osebje, nujne servisne službe, trgovce in trgovke, ki se žrtvujejo za naše skupno zdravje.

Prav koronavirus, ta nevidni sovražnik, proti kateremu bijemo bitko, ogroža temeljne postulate demokracije, kot so svoboda, odprtost, zdravje ... Odtujevanje družbe, zapiranje za štirimi zidovi, brezstičnost, digitalizirana izolacija, medgeneracijski konflikt ... nova realnost, s katero se sooča ves globalni svet, ne le Slovenija.

Ob današnji slovesnosti je primerno, da poudarimo srž reformatorskega gibanja, ki se skriva prav v moči posameznika kot človeka, v njegovi individualni svobodi in družbeni odgovornosti. Moderna družba, ki ji pripadamo, ne sme zanemariti razsežnosti duhovnega sveta na račun tehnološkega napredka in ekonomske rasti. Ne sme spregledati ustvarjalnosti, s katero smo obdarjeni vsi. Izkoristimo ta dar, da ustvarjamo družbo srečnih, izpolnjenih in samozavestnih članov naše dvomilijonske družine. Nevzdržnost razmer nas tako sili v ponovni razmislek, kateri so tisti močni dejavniki povezovanja, sodelovanja, sopomoči in sočutja med slehernim članom te naše slovenske družine. Slovenci smo dolga stoletja previharili razdeljeni in razkosani, a kulturno enotni. Velik prispevek k tej kulturni vzniklosti in samobitnosti moramo pripisati prav zgodovinski vlogi slovenskih evangeličanov. Prvine, ki si jih lahko pripisujemo kot narodu lastne, so se skozi zgodovinski proces 
izmojstrile do odlike. Morda bomo prav zavoljo njih in z njimi iz krize izšli še boljši, srečnejši in bolj izpopolnjeni.

Vsem Slovencem milost, mir, usmiljenje ... naj bodo te prve slovenske besede v prvi slovenski knjigi Katekizem iz leta 1550 popotnica vsakomur izmed nas, drage državljanke in državljani Republike Slovenije, da se ozremo vase $\mathrm{v}$ teh težkih in negotovih časih in da prepoznamo to seme dobrote in usmiljenja v najlepši luči, kot seme solidarnosti, sožitja, miru in milosti drug do drugega in drugega ob drugem. 